\title{
MESSIANIC EXPECTATIONS IN THE EARLY POST-EXILIC PERIOD ${ }^{1}$
}

\author{
Wolter H. Rose
}

This thesis examines (1) the identity of the coming ruler who is given the name Zemah (צמח, usually translated 'the Branch'), the main character in the צמח oracles (Zc. 3:8 and 6:9-15) in the visions in Zechariah 1-6, and (2) the nature of the expectations set on this figure. It is argued that a wrong translation of the word צמח is one of the factors that has led to flawed interpretation of these oracles. The real meaning of צמח, 'vegetation, greenery, growth', implies that the background for the interpretation of the צמח oracles in Zechariah should not be found in the plant imagery of Isaiah 11:1 (where different terminology and different imagery is used). The use of the צמח imagery in Zechariah 3:8 and 6:12-13 is analogous to that found in Jeremiah 23:5, where in a time of collapse of the monarchy the same צמח imagery is used to evoke the idea of an intervention by $\mathrm{YHWH}$ as the only means for guaranteeing the restoration of the monarchy. In this scenario, 'David' will not contribute, but only receive. The adjective צ' does not raise the issue of legitimacy, as has often been claimed, but has the usual meaning 'righteous', an interpretation that can be supported from the context of the passage. The claim that there are many examples of North-West Semitic $s d q$ meaning 'legitimate' is tested and found seriously wanting.

The choice of the word צמח as the name of the coming ruler, a name with a distinctive message, combined with other features, such as the crowning of Joshua rather than Zerubbabel, and the consistent future reference of the coming of Zemah, make an identification of Zemah with Zerubbabel

!W.H. Rose, Zerubbabel and Zemah: Messianic Expectations in the Early PostExilic Period (unpublished D.Phil. thesis, Oxford University, 1997); supervisor: Professor H.G.M. Williamson. 
untenable. Only an identification of Zemah with an unidentified future figure has the explanatory power to deal satisfactorily with all the features of the double portrait of Zemah in Zechariah 3 and 6. Such an identification implies that Zemah may be called a messianic figure, defined as a future ruler figure modelled on David who is sent by God to inaugurate an era of salvation and bliss.

The choice of the name Zemah suggests that, after a period of several decades (a period which included exile into Babylon), the situation and prospects with regard to the Davidic dynasty at the time of the prophet Zechariah was not much different from that at the time of the prophet Jeremiah. What Jeremiah's oracle conveyed is still true in this new situation: historical developments as such will not bring in a new monarchy. A personal intervention by God is still called for.

The high priest Joshua and his colleagues are said to be 'men of portent' (3:8). The nature of the portent becomes more specific in the embedding of the second צמח sacle of 6:12-15 in a symbolic action in which a crown is set upon the head of Joshua the high priest. On the basis of the rather general word used for 'crown', I argue that setting a crown on the head of the high priest should be distinguished from a proper coronation: in this context it serves a symbolic function. The crown points to the promised rule of Zemah and is set upon the head of the high priest to make the priesthood a guarantee for the fulfilment of this promise. Nothing changes in the political position or status of the high priest.

In another passage (3:7), Joshua the high priest is charged with a new responsibility over the temple area (either jurisdiction, or government and administration). This is a prerogative that formerly belonged to the king. The word in the last clause of the verse is usually translated 'access', which is then taken to mean that the high priest is promised access to the heavenly council. There is no evidence that a form of the root הלך can be used in this way, and the interpretation fails to provide an adequate explanation for the plural. It is preferable to interpret the form as a verbal form, a D-stem participle, 'those who go'. The promise is not so much 
one of direct access, but more of figures who serve as mediators between the heavenly council and the high priest. Loyal performance of the high priest will be rewarded by a new relationship with persons who function as a bridge between heavenly council and earth, possibly prophets.

The second צמח oracle includes an extremely vague reference to a priest by the throne of the coming ruler (6:13). His role is probably that of a counsellor to the ruler. There is no evidence here for a joint rule of the coming ruler and the priest (so-called 'diarchy'). Zechariah 4:14 does not provide such evidence either: it has been a mistake to interpret the beginning of the phrase 'the two sons of oil who stand by the Lord of the whole earth' as referring to anointed ones. These figures are not to be seen as human leaders on earth, but as heavenly beings in the council of $\mathrm{YHWH}$, as the use of the phrase 'stand by' indicates.

Proposals have been made to consider part of the oracles in the vision reports in Zechariah 1-6 (including the two צמח oracles) as secondary, and to date them to a period before the visions. In this way some of the obstacles to the identification of Zemah with Zerubbabel could possibly be removed. On closer examination these proposals appear to be based on dubious grounds. Most of the features that are considered to be contradictory or to create tension, and thus are taken to indicate the secondary status of those parts of the oracles in which they are found, can be explained in a different, more satisfactory way.

The elevation of the high priesthood, either as a matter of historical fact or as a piece of propaganda, is usually identified as the motive of the redactor which led him to alter the text. Such a motive is difficult to fit in the early Persian period, and there is surprisingly little evidence in the text as we have it now to support the reconstruction of this particular motive as the driving force behind the alterations.

The alteration theory also creates a conflicting picture of the redactor. On the one hand, he is censured for his incompetence on a macro level, because he failed to carry out all alterations which one would expect to have happened in this scenario; on the other hand, he is given the credit for some 
sophisticated minor changes. Finally, there is little evidence in the early versions to support the alteration theory. In the light of such problems, the recent trend to abandon proposals to find secondary additions or a rewritten oracle can be seen as commendable.

The final oracle in Haggai 2:20-23 is generally taken to imply an imminent restoration of the monarchy. This interpretation is questioned. The royal connotations of words like לקח (laqăh), עבר ('abăd), and בחר (bahăr) have been overstated. Each of these words can be used in connection with kings, but the use of them is not limited to that. Both the terminology (חות [ [ [ Haggai 2:23 are wrong for a kingship interpretation of the seal imagery to work (there is a similar problem in Je. 22:24-26). One has to conclude that either the prophet confused the imagery, or that the imagery was not meant to convey the idea of kingship.

Seal imagery (in which 'seal' is to be distinguished from 'signet' [טבעת, țăbbăcăt]) is used in the Old Testament and in the Ancient Near East to evoke the idea of special care or protection for a person who has a high personal value for someone. This seal imagery is used in a variety of contexts. Examples include love poetry and government correspondence. The use of this imagery in different contexts suggests that kingship is not essential to the image. YHWH's promise to Zerubbabel should therefore be interpreted as comprising special protection for God's chosen servant at a time of substantial changes in the political landscape. This interpretation leaves no room to call Haggai's final oracle royal or messianic. In the absence of other oracles dealing with the theme of kingship in Haggai, one has to conclude that we cannot tell what Haggai's expectations concerning the restoration of the monarchy or messianism were. 